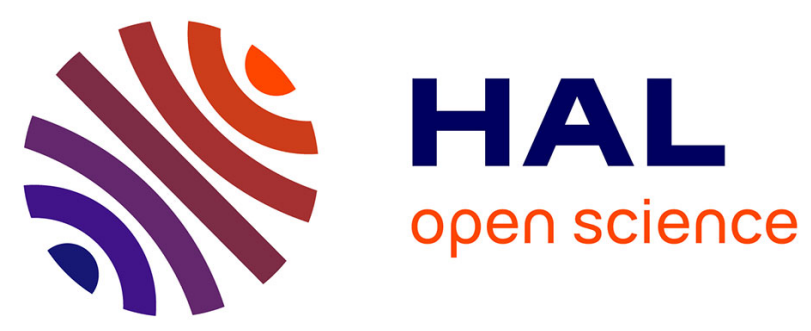

\title{
Antithrombotic efficacy of bivalirudin compared to unfractionated heparin during percutaneous coronary intervention for acute coronary syndrome
}

Corinne Frere, Marc Laine, Gilles Lemesle, Pierre-Emmanuel Morange, Franck

Paganelli, Francoise Dignat-George, Noémie Resseguier, Régis Guieu,

Laurence Camoin-Jau, Laurent Bonello

\section{To cite this version:}

Corinne Frere, Marc Laine, Gilles Lemesle, Pierre-Emmanuel Morange, Franck Paganelli, et al.. Antithrombotic efficacy of bivalirudin compared to unfractionated heparin during percutaneous coronary intervention for acute coronary syndrome. Platelets, 2019, 30 (1), pp.105-111. 10.1080/09537104.2017.1384541 . hal-01762121

\section{HAL Id: hal-01762121 \\ https://hal-amu.archives-ouvertes.fr/hal-01762121}

Submitted on 10 Apr 2018

HAL is a multi-disciplinary open access archive for the deposit and dissemination of scientific research documents, whether they are published or not. The documents may come from teaching and research institutions in France or abroad, or from public or private research centers.
L'archive ouverte pluridisciplinaire HAL, est destinée au dépôt et à la diffusion de documents scientifiques de niveau recherche, publiés ou non, émanant des établissements d'enseignement et de recherche français ou étrangers, des laboratoires publics ou privés. 


\title{
Antithrombotic efficacy of bivalirudin compared to unfractionated heparin during percutaneous coronary intervention for acute coronary syndrome
}

Corinne Frere, Marc Laine, Gilles Lemesle, Pierre-Emmanuel Morange, Franck Paganelli, Francoise Dignat-George, Noemie Resseguier, Regis Guieu, Laurence Camoin-Jau et Laurent Bonello

\begin{abstract}
Bivalirudin is associated with an increased risk of acute stent thrombosis (AST) compared to unfractionated heparin (UFH) in acute coronary syndrome patients (ACS) during shortduration percutaneous coronary intervention (PCI). The mechanisms involved are unknown. We aimed to investigate the antithrombotic efficacy of bivalirudin compared to UFH during PCI. In a monocenter study, we prospectively enrolled 30 patients undergoing PCI for a nonST elevation ACS. They were randomly assigned to a single intravenous (IV) bolus of UFH (70 IU/kg) or an IV bolus of bivalirudin $0.75 \mathrm{mg} / \mathrm{kg}$ followed by a $1.75 \mathrm{mg} / \mathrm{kg} / \mathrm{h}$ infusion during PCI. All patients received a loading dose (LD) of $180 \mathrm{mg}$ of ticagrelor at the time of PCI. The VASP index and activated partial thromboplastin time (aPTT) were used to assess the course of platelet reactivity (PR) and antithrombotic activity. The two groups were similar regarding baseline, angiographic, and interventional characteristics. There was no difference between the two groups in the course of PR following ticagrelor LD. An optimal PR inhibition was obtained $4 \mathrm{~h}$ after the LD of ticagrelor. The level of antithrombotic activity was significantly lower in the bivalirudin group compared to the UFH group $(p<0.001)$ during PCI but similar at 2 and $4 \mathrm{~h}$ post-PCI. We observed that, in ACS undergoing PCI, the antithrombotic efficacy of an IV bolus of bivalirudin is significantly lower than that of a 70IU/kg UFH bolus. This could contribute to the excess in thrombotic acute events observed during short-duration PCI.
\end{abstract}

Keywords: Acute myocardial infarction, platelet aggregation, stent thrombosis, thrombin

\section{Introduction}

Bivalirudin is a direct and specific thrombin inhibitor that can be used during percutaneous coronary interventions (PCIs) in the setting of acute coronary syndrome (ACS) [Management of Acute Coronary Syndromes in Patients Presenting without Persistent ST-Segment Elevation of the European Society of Cardiology. ESC Guidelines for the management of acute coronary syndromes in patients presenting without persistent ST-segment elevation: Task Force for the Management of Acute Coronary Syndromes in Patients Presenting without Persistent ST-Segment Elevation of the European Society of Cardiology (ESC). Eur Heart J 2015;2016(37):267-315. ]. It has several potential advantages over unfractionated heparin (UFH). Indeed, it binds to both soluble (free) and clot-bound thrombin and decreases platelet aggregation through thrombin-induced inhibition of platelet aggregation [Kimmelstiel C, Zhang P, Kapur NK, Weintraub A, Krishnamurthy B, Castaneda V, Covic L, Kuliopulos A. Bivalirudin is a dual inhibitor of thrombin and collagen-dependent platelet activation in patients undergoing percutaneous coronary intervention. Circ Cardiovasc Interv 2011;4:171179.,3 Braun D, Knipper A, Orban M, Sibbing D, Petzold T, Braun S, Schulz S, Hausleiter J, Kastrati A, Mehilli J, Massberg S. Platelet function and coagulation in patients with STEMI and peri-interventional clopidogrel plus heparin vs. prasugrel plus bivalirudin therapy (BRAVE 4 substudy). Thromb Res 2016; 137:72-78.]. Several trials have demonstrated a net clinical benefit of bivalirudin compared to UFH with and without glycoprotein (GP) 2b/3a inhibitors, thanks to a reduction in bleedings [Navarese EP, Schulze V, Andreotti F, 
Kowalewski M, Kołodziejczak M, Kandzari DE, Rassaf T, Gorny B, Brockmeyer M, Meyer C, Berti S, Kubica J, Kelm M, Valgimigli M. Comprehensive meta-analysis of safety and efficacy of bivalirudin versus heparin with or without routine glycoprotein IIb/IIIa inhibitors in patients with acute coronary syndrome. JACC Cardiovasc Interv 2015; 8:201-213, Han Y, Guo J, Zheng Y, Zang H, Su X, Wang Y, Chen S, Jiang T, Yang P, Chen J, Jiang D, Jing Q, Liang Z, Liu H, Zhao X, Li J, Li Y, Xu B, Stone GW. BRIGHT Investigators, bivalirudin vs heparin with or without tirofiban during primary percutaneous coronary intervention in acute myocardial infarction: The BRIGHT randomized clinical trial. Jama 2015; 313:1336-1346.]. However, despite its theoretical advantages over UFH, bivalirudin use was associated with an increased risk of acute $(<24 \mathrm{~h}$ ) stent thrombosis (AST) [Navarese EP, Schulze V, Andreotti F, Kowalewski M, Kołodziejczak M, Kandzari DE, Rassaf T, Gorny B, Brockmeyer M, Meyer C, Berti S, Kubica J, Kelm M, Valgimigli M. Comprehensive meta-analysis of safety and efficacy of bivalirudin versus heparin with or without routine glycoprotein IIb/IIIa inhibitors in patients with acute coronary syndrome. JACC Cardiovasc Interv 2015;8:201-213; Steg PG, Van't Hof A, Hamm CW, Clemmensen P, Lapostolle F, Coste P, Berg JT, Grunsven PV, Eggink GJ, Nibbe L, Zeymer U, Campo Dell' Orto M, Nef H, Steinmetz J, Soulat L, Huber K, Deliargyris EN, Bernstein D, Schuette D, Prats J, Clayton T, Pocock S, Hamon M, Goldstein P. EUROMAX Investigators, bivalirudin started during emergency transport for primary PCI. N Engl J Med 2013;369:207-2217] The mechanism responsible for such excess of AST remains unknown.

The care of ACS is based on the dual inhibition of platelet activity and thrombin to prevent thrombus formation and growth [1 Management of Acute Coronary Syndromes in Patients Presenting without Persistent ST-Segment Elevation of the European Society of Cardiology. ESC Guidelines for the management of acute coronary syndromes in patients presenting without persistent ST-segment elevation: Task Force for the Management of Acute Coronary Syndromes in Patients Presenting without Persistent ST-Segment Elevation of the European Society of Cardiology (ESC). Eur Heart J 2015;2016(37):267-315 ; Silvain J, Collet J-P, Nagaswami C, Beygui F, Edmondson KE, Bellemain-Appaix A, Cayla G, Pena A, Brugier D, Barthelemy O, Montalescot G, Weisel JW. Composition of coronary thrombus in acute myocardial infarction. J Am Coll Cardiol 2011; 57:1359-1367; Brummel-Ziedins K, Undas A, Orfeo T, Gissel M, Butenas S, Zmudka K, Mann KG. Thrombin generation in acute coronary syndrome and stable coronary artery disease: Dependence on plasma factor composition. J Thromb Haemost 2008; 6:104-110]. Of importance, the level of P2Y12-ADP receptor blockade necessary to prevent stent thrombosis is delayed for at least $2 \mathrm{~h}$ after the loading dose (LD) of P2Y12-ADP receptor antagonist in ACS [Parodi G, Valenti R, Bellandi B, Migliorini A, Marcucci R, Comito V, Carrabba N, Santini A, Gensini GF, Abbate R, Antoniucci D. Comparison of prasugrel and ticagrelor loading doses in ST-segment elevation myocardial infarction patients: RAPID (Rapid Activity of Platelet Inhibitor Drugs) primary PCI study. J Am Coll Cardiol 2013;61:1601-1606; Tantry US, Bonello L, Aradi D, Price MJ, Jeong Y-H, Angiolillo DJ, Stone GW, Curzen N, Geisler T, Ten Berg J, Kirtane A, SillerMatula J, Mahla E, Becker RC, Bhatt DL, Waksman R, Rao SV, Alexopoulos D, Marcucci R, Reny J-L, Trenk D, Sibbing D, Gurbel PA. Working Group on On-Treatment Platelet Reactivity, Consensus and update on the definition of on-treatment platelet reactivity to adenosine diphosphate associated with ischemia and bleeding. J Am Coll Cardiol 2013; 62:2261-2273]. In addition, during PCI, achieving high levels of thrombin inhibition is critical to prevent thrombus formation [Management of Acute Coronary Syndromes in Patients Presenting without Persistent ST-Segment Elevation of the European Society of Cardiology. ESC Guidelines for the management of acute coronary syndromes in patients presenting without persistent ST-segment elevation: Task Force for the Management of Acute 
Coronary Syndromes in Patients Presenting without Persistent ST-Segment Elevation of the European Society of Cardiology (ESC). Eur Heart J 2015;2016(37):267-315]. A recent analysis of the HORIZONS-AMI trial observed that short procedural duration of PCI was associated with an increased risk of AST despite otherwise favorable features [Tamez $\mathrm{H}$, Pinto DS, Kirtane AJ, Litherland C, Yeh RW, Dangas GD, Mehran R, Deliargyris EN, Ortiz G, Gibson CM, Stone GW. Effect of short procedural duration with bivalirudin on increased risk of acute stent thrombosis in patients with STEMI: A secondary analysis of the HORIZONS-AMI randomized clinical trial. JAMA Cardiol 2017. doi:10.1001/jamacardio.2016.5669]. The mechanism involved in this higher risk of AST during short and simple PCI is unknown but may involve the antithrombotic activity of bivalirudin.

We hypothesized that the antithrombotic activity of bivalirudin may be lower compared to UFH during PCI, which could lead to increased thrombotic events. We therefore compared the course of P2Y12-ADP receptor inhibition and thrombin inhibition between UFH and bivalirudin in non-ST elevation ACS (NSTE-ACS) patients undergoing PCI.

\section{Methods}

We performed a monocenter prospective randomized controlled open-label study between October 2016 and January 2017. This study was a prespecified sub-study of a larger clinical trial: NCT02428725. Consecutive intermediate, high-risk, or very-high risk ACS patients according to ESC guidelines were eligible [Management of Acute Coronary Syndromes in Patients Presenting without Persistent ST-Segment Elevation of the European Society of Cardiology. ESC Guidelines for the management of acute coronary syndromes in patients presenting without persistent ST-segment elevation: Task Force for the Management of Acute Coronary Syndromes in Patients Presenting without Persistent ST-Segment Elevation of the European Society of Cardiology (ESC). Eur Heart J 2015;2016(37):267-315 ]. Informed consents were obtained for all patients before inclusion. Patients were included after coronary angiography if PCI was indicated. The study protocol conforms to the ethical guidelines of the 1975 Declaration of Helsinki as reflected in a priori approval by the institution's human research committee. The local ethic committee of our institution approved the study. All patients were naives of P2Y12-ADP receptor blockers and anticoagulant at the time of inclusion. No P2Y12-ADP receptor pretreatment was used. PCI was performed through the radial route in all patients. All implanted stents were drug-eluting stents.

\section{Antithrombotic therapy}

On inclusion, at the time of PCI, patients were randomized to UFH or bivalirudin using a computer-generated randomization list (1:1). All patients received an intravenous (IV) bolus of aspirin $250 \mathrm{mg}$ and a $180 \mathrm{mg} \mathrm{LD}$ of ticagrelor at the time of PCI.

In the UFH group, patients received an IV bolus of $70 \mathrm{IU} / \mathrm{kg}$ of UFH as soon as PCI was started. No further bolus was given during or after PCI.

In the bivalirudin group, patients received an IV bolus of $0.75 \mathrm{mg} / \mathrm{kg}$, as soon as PCI was started, immediately followed by an IV infusion of $1.75 \mathrm{mg} / \mathrm{kg} / \mathrm{h}$. The infusion was stopped at the end of the PCI [1 Management of Acute Coronary Syndromes in Patients Presenting without Persistent ST-Segment Elevation of the European Society of Cardiology. ESC Guidelines for the management of acute coronary syndromes in patients presenting without 
persistent ST-segment elevation: Task Force for the Management of Acute Coronary Syndromes in Patients Presenting without Persistent ST-Segment Elevation of the European Society of Cardiology (ESC). Eur Heart J 2015;2016(37):267-315 ]. The maintenance dose (MD) of aspirin was $75 \mathrm{mg}$ and the MD of ticagrelor was $90 \mathrm{mg}$ twice daily in all patients [Management of Acute Coronary Syndromes in Patients Presenting without Persistent STSegment Elevation of the European Society of Cardiology. ESC Guidelines for the management of acute coronary syndromes in patients presenting without persistent STsegment elevation: Task Force for the Management of Acute Coronary Syndromes in Patients Presenting without Persistent ST-Segment Elevation of the European Society of Cardiology (ESC). Eur Heart J 2015;2016(37):267-315 ].

\section{Exclusion criteria}

The exclusion criteria were persistent ST-elevation ACS, anticoagulant therapy, severe kidney failure (creatinin clearance $<30 \mathrm{~mL} / \mathrm{min}$ ), hemodialysis, contraindication to ticagrelor, bleeding disorder, cardiogenic shock, cardiac arrest, contraindication to antiplatelet therapy, ongoing therapy with P2Y12-ADP blockers, platelet count $<100 \mathrm{G} / \mathrm{L}$, history of bleeding diathesis, history of stroke, recent surgery ( $<1$ month), use of medication with known interference with ticagrelor, bradycardia, history of heparin-induced thrombocytopenia, GP $2 \mathrm{~b} / 3 \mathrm{a}$ inhibitors.

\section{Blood samples and laboratory analysis}

Blood samples were drawn by atraumatic venipuncture of the antecubital vein. The initial blood drawn was discarded to avoid platelet activation induced by needle puncture; blood was collected into a Vacutainer containing 3.8\% trisodium citrate filled to capacity. The Vacutainer was inverted three to five times for gentle mixing and sent immediately to the hemostasis laboratory. Activated partial thromboplastin time (aPTT) was performed on a STAR-R Evolution ${ }^{\circledR}$ analyzer using the STA®-PTT Automate 5 reagent (both Stago, Asnières, France). aPTT measurements were performed before UHF or bivalirudin infusion, 5 min after the bolus (during PCI) and then $2 \mathrm{~h}$ after the PCI. Platelet reactivity (PR) was measured using the VASP index. VASP index phosphorylation analysis was performed within $24 \mathrm{~h}$ of blood collection by an experienced investigator using the CY-QUANT VASP/P2Y12 enzyme-linked immunoabsorbent assay (Biocytex, Marseille, France) [Bonello L, Laine M, Camoin-Jau L, Noirot F, Guieu R, Dignat-George F, Paganelli F, Frere C. Onset of optimal P2Y12-ADP receptor blockade after ticagrelor and prasugrel intake in Non-ST elevation acute coronary syndrome. Thromb Haemost 2015; 114:702-707]. Briefly, after the first step of parallel whole-blood sample activation with PGE1 and PGE1 + ADP, platelets from the sample are lysed, allowing released VASP to be captured by an anti-human VASP antibody which is coated in the microtiter plate. Then, a peroxidase-coupled anti-human VASP-P antibody binds to phosphorylated serine 239 antigenic determinant of VASP. The bound enzyme peroxidase is then revealed by its activity on TMB substrate over a predetermined time. After stopping the reaction, absorbance at $450 \mathrm{~nm}$ is directly related to the concentration of VASP-P contained in the sample. The PR index (PRI) VASP was calculated using optical density (OD $450 \mathrm{~nm}$ ) of samples incubated with PGE1 or PGE1 and ADP according to the formula: PRI-VASP $=[($ OD $450 \mathrm{~nm}(\mathrm{PGE} 1)-\mathrm{OD} 450 \mathrm{~nm}(\mathrm{PGE} 1+\mathrm{ADP})) / \mathrm{OD} 450 \mathrm{~nm}$ (PGE1)] $\times 100$. Optimal PR inhibition was defined as a PRI-VASP $<50 \%$, according to the consensus document on the definition of high on-treatment PR [Tantry US, Bonello L, Aradi D, Price MJ, Jeong Y-H, Angiolillo DJ, Stone GW, Curzen N, Geisler T, Ten Berg J, Kirtane A, Siller-Matula J, Mahla E, Becker RC, Bhatt DL, Waksman R, Rao SV, Alexopoulos D, 
Marcucci R, Reny J-L, Trenk D, Sibbing D, Gurbel PA. Working Group on On-Treatment Platelet Reactivity, Consensus and update on the definition of on-treatment platelet reactivity to adenosine diphosphate associated with ischemia and bleeding. J Am Coll Cardiol 2013; 62:2261-2273].

\section{Clinical follow-up}

All patients were followed in-hospital for ischemic and bleeding events. Ischemic events included death, myocardial infarction, and urgent revascularization. Bleedings included $\mathrm{BARC}>2$.

\section{Statistical analysis}

Categorical variables were expressed as frequencies and percentages and continuous variables as median and interquartile range (IQR). Categorical variables were compared using chisquare test or Fisher's exact test, as appropriate, and continuous ones using Mann-Whitney test. All statistical tests were two-tailed, and a $p$-value $<0.05$ was considered statistically significant. All the statistical analyses were performed using the Graphpad Prism software v5.0 for windows (Graphpad Software Inc., San Diego, USA).

\section{Results}

\section{Baseline characteristics of the population}

Thirty patients were prospectively included in the study and randomized to bivalirudin $(n=15)$ or UFH $(n=15)$. The baseline characteristics of the two groups are shown in Table I. The median age was 63 years, and both groups had similar baseline characteristics including biological parameters. Diabetes was present in $30 \%$ of patients. Half of patients were admitted for non-ST elevation myocardial infarction (NSTEMI).

\section{Angiographic characteristics}

The angiographic and interventional characteristics of the two groups are shown in Table II. The number of diseased and treated vessels was similar between the two groups. Both groups had identical number of stents implanted during the procedure. Procedure times were also identical between the two groups.

\section{Platelet reactivity}

The course of PR inhibition assessed by the VASP index was similar at all time points between the two groups. At baseline all patients had a PRI-VASP $\geq 50 \%$ (median, $92.5 \%$; IQR, 83-93\% in the bivalirudin group versus 94\%; IQR, 88-96\% in the UFH group, $p=n s$ ). The median VASP was significantly decreased $2 \mathrm{~h}$ after the procedure as compared to baseline for both groups ( $p=0.0071$ and $p=0.0002$, respectively, for the bivalirudin and the UFH groups); of note, two patients (13\%) in each group did not reach a VASP $<50 \% 2 \mathrm{~h}$ after the LD. Finally, all patients had a VASP $<50 \%$ in both groups at $4 \mathrm{~h}$ post-PCI (Figure $1)$.

Figure 


\section{Time course of aPTT}

The baseline aPTT did not differ between the groups (bivalirudin vs. UFH group: median $34.5 \mathrm{~s}$; IQR, 32.6-37.8 vs. $32.35 \mathrm{~s}$; IQR $28.8-36.1, p=\mathrm{ns})$. On the contrary, 5 min. after the bolus of UFH or bivalirudin, the median aPTT was $145.9 \mathrm{~s}(\mathrm{IQR}, 114-165)$ in the bivalirudin group whereas all patients had an aPTT $>200$ sin the UFH group $(p<0.0001)$ (Figure 2). The values of aPTT decreased $2 \mathrm{~h}$ after PCI in both groups with no difference between groups ( $p=\mathrm{ns}$ for between groups).

\section{Clinical follow-up}

During the 1-month follow-up, no ischemic events were recorded. One BARC three bleeding events were seen in each group during the in-hospital stay $(p=n s)$.

\section{Discussion}

In the present study, we observed that during PCI for an ACS, the antithrombotic efficacy of bivalirudin following the IV bolus was inferior to the IV bolus of UFH. In addition, we confirmed that ticagrelor has a delayed onset of action until $2 \mathrm{~h}$ post-LD in NSTE-ACS. Our results demonstrate that in bivalirudin-treated patients, the protection against AST through thrombin and platelet inhibition is suboptimal during PCI. These results may explain the paradoxical findings by Tamez et al. of an increased AST frequency in the case of short procedures in bivalirudin-treated patients [Tamez H, Pinto DS, Kirtane AJ, Litherland C, Yeh RW, Dangas GD, Mehran R, Deliargyris EN, Ortiz G, Gibson CM, Stone GW. Effect of short procedural duration with bivalirudin on increased risk of acute stent thrombosis in patients with STEMI: A secondary analysis of the HORIZONS-AMI randomized clinical trial. JAMA Cardiol 2017. doi:10.1001/jamacardio.2016.5669].

The pathophysiology of ACS requires contemporary blockade of the coagulation cascade and of platelet activity, which are closely linked, to prevent thrombus formation and growth [Management of Acute Coronary Syndromes in Patients Presenting without Persistent STSegment Elevation of the European Society of Cardiology. ESC Guidelines for the management of acute coronary syndromes in patients presenting without persistent STsegment elevation: Task Force for the Management of Acute Coronary Syndromes in Patients Presenting without Persistent ST-Segment Elevation of the European Society of Cardiology (ESC). Eur Heart J 2015;2016(37):267-315]. Thrombin is a key actor of thrombosis during ACS. It not only plays a role in clot formation through the coagulation cascade but also participates in platelet activation through specific receptors [De Caterina R, Husted S, Wallentin L, Andreotti F, Arnesen H, Bachmann F, Baigent C, Huber K, Jespersen J, Kristensen SD, Lip GYH, Morais J, Rasmussen LH, Siegbahn A, Verheugt FWA, Weitz JI. European society of cardiology working group on thrombosis task force on anticoagulants in heart disease, general mechanisms of coagulation and targets of anticoagulants (Section I). Position paper of the ESC working group on thrombosis-task force on anticoagulants in heart disease. Thromb Haemost 2013; 109:569-579]. Bivalirudin is a direct thrombin inhibitor (DTI), which is an alternative to heparin during PCI [Management of Acute Coronary Syndromes in Patients Presenting without Persistent ST-Segment Elevation of the European Society of Cardiology. ESC Guidelines for the management of acute coronary syndromes in patients presenting without persistent ST-segment elevation: Task Force for the Management of Acute Coronary Syndromes in Patients Presenting without Persistent ST-Segment Elevation of the European Society of Cardiology (ESC). Eur Heart J 2015;2016(37):267- 
315 ]. Its theoretical advantages over UFH include a stable and reproducible direct thrombin inhibition, the ability to bind to free thrombin as well as clot-bound thrombin and to inhibit platelet aggregation mediated by thrombin [Schneider DJ, Keating F, Sobel BE. Greater inhibitory effects of bivalirudin compared with unfractionated heparin plus eptifibatide on thrombin-induced platelet activation. Coron Artery Dis 2006; 17:71-476]. In addition, bivalirudin as a shorter half-life compared to heparin, which is of interest to reduce bleedings [Garcia DA, Baglin TP, Weitz JI, Samama MM. American college of chest physicians, parenteral anticoagulants: antithrombotic therapy and prevention of thrombosis, 9th ed: American College of Chest Physicians evidence-based clinical practice guidelines. Chest $2012 ; 141: 24 S-43 S$ ]. In clinical trials, bivalirudin showed similar efficacy in ischemic events and improved safety, thanks to reduced bleedings compared to heparin [Navarese EP, Schulze V, Andreotti F, Kowalewski M, Kołodziejczak M, Kandzari DE, Rassaf T, Gorny B, Brockmeyer M, Meyer C, Berti S, Kubica J, Kelm M, Valgimigli M. Comprehensive metaanalysis of safety and efficacy of bivalirudin versus heparin with or without routine glycoprotein IIb/IIIa inhibitors in patients with acute coronary syndrome. JACC Cardiovasc Interv 2015; 8:201-213; Han Y, Guo J, Zheng Y, Zang H, Su X, Wang Y, Chen S, Jiang T, Yang P, Chen J, Jiang D, Jing Q, Liang Z, Liu H, Zhao X, Li J, Li Y, Xu B, Stone GW. BRIGHT Investigators, bivalirudin vs heparin with or without tirofiban during primary percutaneous coronary intervention in acute myocardial infarction: The BRIGHT randomized clinical trial. Jama 2015; 313:1336-1346]. However, an increased risk of early AST with bivalirudin was constantly observed [Navarese EP, Schulze V, Andreotti F, Kowalewski M, Kołodziejczak M, Kandzari DE, Rassaf T, Gorny B, Brockmeyer M, Meyer C, Berti S, Kubica J, Kelm M, Valgimigli M. Comprehensive meta-analysis of safety and efficacy of bivalirudin versus heparin with or without routine glycoprotein IIb/IIIa inhibitors in patients with acute coronary syndrome. JACC Cardiovasc Interv 2015;8:201-213; Steg PG, Van't Hof A, Hamm CW, Clemmensen P, Lapostolle F, Coste P, Berg JT, Grunsven PV, Eggink GJ, Nibbe L, Zeymer U, Campo Dell' Orto M, Nef H, Steinmetz J, Soulat L, Huber K, Deliargyris EN, Bernstein D, Schuette D, Prats J, Clayton T, Pocock S, Hamon M, Goldstein P. EUROMAX Investigators, bivalirudin started during emergency transport for primary PCI. N Engl J Med 2013; 369:207-2217]. In the HORIZON AMI study [5 Stone GW, Witzenbichler B, Guagliumi G, Peruga JZ, Brodie BR, Dudek D, Kornowski R, Hartmann F, Gersh BJ, Pocock SJ, Dangas G, Wong SC, Kirtane AJ, Parise H, Mehran R. HORIZONS-AMI Trial Investigators, bivalirudin during primary PCI in acute myocardial infarction. N Engl J Med 2008;358:2218-2230], bivalirudin was associated with an excess of AST after the percutaneous procedure, which was again apparent in the EUROMAX trial [7 Steg PG, Van't Hof A, Hamm CW, Clemmensen P, Lapostolle F, Coste P, Berg JT, Grunsven PV, Eggink GJ, Nibbe L, Zeymer U, Campo Dell' Orto M, Nef H, Steinmetz J, Soulat L, Huber K, Deliargyris EN, Bernstein D, Schuette D, Prats J, Clayton T, Pocock S, Hamon M, Goldstein P. EUROMAX Investigators, bivalirudin started during emergency transport for primary PCI. N Engl J Med 2013; 369:207-2217]. In a recent study, we investigated how long thrombin generation inhibition lasted following bivalirudin versus heparin bolus after PCI, to better delineate the potential interest of prolonged bivalirudin infusion as proposed in the recent guidelines [Laine M, Frere C, Cuisset T, Paganelli F, Morange P-E, Dignat-George F, Berbis J, Camoin-Jau L, Bonello L. Potential mechanism of acute stent thrombosis with bivalirudin following percutaneous coronary intervention in acute coronary syndromes. Int J Cardiol 2016; 220:496-500, Ibanez B, James S, Agewall S, Antunes MJ, Bucciarelli-Ducci C, Bueno H, Caforio ALP, Crea F, Goudevenos JA, Halvorsen S, Hindricks G, Kastrati A, Lenzen MJ, Prescott E, Roffi M, Valgimigli M, Varenhorst C, Vranckx P, WidimskÝ P; ESC Scientific Document Group. The Task Force for the management of acute myocardial infarction in patients presenting with ST-segment elevation of the European Society of Cardiology (ESC) 
2017 ESC guidelines for the management of acute myocardial infarction in patients presenting with ST-segment elevation. Eur Heart J 2017; 00:1-66.

doi:10.1093/eurheartj/ehx393]. In this previous study, we observed that the short half-life of bivalirudin compared to UFH may participate in the occurrence of early AST during the first hours following PCI when P2Y12-ADP receptor antagonists are still not biologically active. Interestingly, a recent analysis of the HORIZON-AMI trial observed that shorter PCI procedures were also associated with an increased risk of AST with bivalirudin despite otherwise favorable features of the procedures [Tamez H, Pinto DS, Kirtane AJ, Litherland C, Yeh RW, Dangas GD, Mehran R, Deliargyris EN, Ortiz G, Gibson CM, Stone GW. Effect of short procedural duration with bivalirudin on increased risk of acute stent thrombosis in patients with STEMI: A secondary analysis of the HORIZONS-AMI randomized clinical trial. JAMA Cardiol 2017. doi:10.1001/jamacardio.2016.5669]. This finding is puzzling since shorter PCIs are considered to be at lower risk of ischemic events with less stent, less multivessel stenting, and less thrombus. The present study thus aimed to investigate perprocedural antithrombotic efficacy through evaluation of aPTT following the bolus of heparin and bivalirudin. We observed a lower antithrombotic efficacy of bivalirudin compared to the guidelines' recommended dose of heparin. This result provides a potential mechanism for this paradoxical increase in AST during short and otherwise simple PCI. Consistent with our results, in the HORIZONS-AMI trial and the following trials, a single bolus of $0.75 \mathrm{mg} / \mathrm{kg}$ bivalirudin was used and compared to a bolus of UFH targeting 200-250 of ACT. However, the manufacturer and the European Medicines Agency recommend to evaluate ACT after the bivalirudin bolus and, if the ACT is $<225 \mathrm{~s}$, to repeat a $0.3 \mathrm{mg} / \mathrm{kg}$ bolus based on the results of the REPLACE 1 and 2 trials [Lincoff M, Bittl JA, Harrington RA, Feit F, Kleiman NS, Jackman JD, Sarembock IJ, Cohen DJ, Spriggs D, Ebrahimi R, Keren G, Carr J, Cohen EA, Betriu A, Desmet W, Kereiakes DJ, Rutsch W, Wilcox RG, De Feyter PJ, Vahanian A, Topol EJ. REPLACE-2 Investigators, bivalirudin and provisional glycoprotein IIb/IIIa blockade compared with heparin and planned glycoprotein IIb/IIIa blockade during percutaneous coronary intervention: REPLACE-2 randomized trial. JAMA 2003; 289:853-863 ; Lincoff AM, Bittl JA, Kleiman NS, Sarembock IJ, Jackman JD, Mehta S, Tannenbaum MA, Niederman AL, Bachinsky WB. Tift-Mann J 3rd, Parker HG, Kereiakes DJ, Harrington RA, Feit F, Maierson ES, Chew DP, Topol EJ; REPLACE-1 Investigators. Comparison of bivalirudin versus heparin during percutaneous coronary intervention (the Randomized Evaluation of PCI Linking Angiomax to Reduced Clinical Events [REPLACE]-1 trial). Am J Cardiol 2004; 93:1092-1096]. This was not implemented in the recent clinical trials and, as suggested by the present study, may translate into insufficient antithrombotic efficacy. Consistent with our findings and this hypothesis, in an in vitro study, investigators observed a suboptimal antithrombin efficacy of the bivalirudin bolus compared to heparin with thrombus being generated on catheters [Maegdefessel L, Buerke M, Schubert S, Reindl I, Michel T, Hauroeder B, Carter JM, Peetz D, Werdan K, Schlitt A. Comparison of bivalirudin, enoxaparin, and unfractionated heparin in preventing cardiac catheter thrombosis. Results of an in-vitro study. Thromb Haemost 2008; 100:693-698].

Studies comparing the antithrombotic activity of bivalirudin and heparin showed mixed results. These studies were based on ACT, which has a limited ability to precisely determine the anticoagulant activity and is very dependent on the test reactive used. In addition, in the REPLACE 1 trial, the heparin dose was 60-70 UI/kg with ACT-based adjustments [Lincoff AM, Bittl JA, Kleiman NS, Sarembock IJ, Jackman JD, Mehta S, Tannenbaum MA, Niederman AL, Bachinsky WB. Tift-Mann J 3rd, Parker HG, Kereiakes DJ, Harrington RA, Feit F, Maierson ES, Chew DP, Topol EJ; REPLACE-1 Investigators. Comparison of bivalirudin versus heparin during percutaneous coronary intervention (the Randomized 
Evaluation of PCI Linking Angiomax to Reduced Clinical Events [REPLACE]-1 trial). Am J Cardiol 2004; 93:1092-1096]. In the REPLACE 2 trial, the dose was reduced to $60 \mathrm{UI} / \mathrm{kg}$ because of the concomitant infusion of GP2b/3a, which may have skewed the biological comparison between heparin and bivalirudin [Lincoff M, Bittl JA, Harrington RA, Feit F, Kleiman NS, Jackman JD, Sarembock IJ, Cohen DJ, Spriggs D, Ebrahimi R, Keren G, Carr J, Cohen EA, Betriu A, Desmet W, Kereiakes DJ, Rutsch W, Wilcox RG, De Feyter PJ, Vahanian A, Topol EJ. REPLACE-2 Investigators, bivalirudin and provisional glycoprotein IIb/IIIa blockade compared with heparin and planned glycoprotein IIb/IIIa blockade during percutaneous coronary intervention: REPLACE-2 randomized trial. JAMA 2003; 289:853863]. Consistent with the guidelines, the dose of heparin was a 70-UI/kg IV bolus in the present study, thus enabling a fair comparison of the two drugs. In addition, we have used the aPTT, which represents a more robust and reproducible test to adequately assess the antithrombotic level. In fact, laboratory-based aPTT was more closely correlated with heparin concentration than bedside-based ACT [Smythe MA, Koerber JM, Nowak SN, Mattson JC, Begle RL, Westley SJ, Balasubramaniam M. Correlation between activated clotting time and activated partial thromboplastin times. Ann Pharmacother 2002; 36:7-11: Atallah S, Liebl M, Fitousis K, Bostan F, Masud F. Evaluation of the activated clotting time and activated partial thromboplastin time for the monitoring of heparin in adult extracorporeal membrane oxygenation patients. Perfusion 2014; 29:456-461].

\section{Limitations}

The sample size of this study is relatively small. We have assessed PR using the VASP index, which is a well-validated assay to measure P2Y12-ADP receptor blockage, but we did not assess the other platelet activation pathways. Although aPTT is a robust mean to assess antithrombotic efficacy, it has some limitations: aPTT may be influenced by coagulopathies, lupus anticoagulant, and raised FVIII levels. In addition, variable but not clinically significant sensitivity of aPTT reagents to DTIs has been highlighted elsewhere.

A direct comparison between UFH and bivalirudin during the time of PCI using specific antiIIa activity area under the curve in order to assess the drug exposure could hardly be possible. The 5-min aPTT was therefore taken as the biological outcome of interest. This easily available test was previously shown to correlate well with the antifactor activity profile [Mousa SA, Zhang F, Aljada A, Chaturvedi S, Takieddin M, Zhang H, Chi L, Castelli MC, Friedman K, Goldberg MM, Linhardt RJ. Pharmacokinetics and pharmacodynamics of oral heparin solid dosage form in healthy human subjects. J Clin Pharmacol 2007; 47:1508-1520].

Although the aPTT is a robust mean to assess antithrombotic efficacy, we acknowledge that it may not be the best test for monitoring bivalirudin. Indeed, it has been previously established that aPTT can overestimate the spiked DTI concentrations in samples with lupus inhibitors or low levels of vitamin K-dependent factors [Love JE, Ferrell C, Chandler WL. Monitoring direct thrombin inhibitors with a plasma diluted thrombin time. Thromb Haemost 2007; 98:234-242]. In addition, variable but not clinically significant sensitivity of APTT reagents to DTIs has been highlighted elsewhere. However, in our cohort, the presence of lupus inhibitors or low levels of vitamin K-dependent factors was eliminated since all patients had a baseline aPPT < 39 s(reference value of the laboratory: $33 \mathrm{~s}$ ) and a baseline aPTT ratio was $<1.2$. Moreover, the use of a modified plasma-diluted thrombin time (dTT), which has been advocated for monitoring DTIs, was not possible in the perspective of a UFH and bivalirudin comparison. 


\section{Conclusion}

The present study suggests that the current protocol of a single bolus of bivalirudin during PCI in ACS may be insufficient in some patients to obtain an optimal antithrombotic effect. This sub optimal biological efficacy could explain the excess in AST observed in the HORIZON trial during otherwise simple and short procedure time PCI.

\section{Acknowledgments}

We would like to thank Pauline Armangau and Floriane Robin for her help and very appreciated work for the present study.

\section{ClinicalTrials.gov Identifier}

NCT02428725

\section{Conflict of interest}

L. Bonello, M. Laine, F. Paganelli received research grants from Astrazeneca. L. Bonello received lectures fee from AstraZeneca and the medicine company.

\section{Disclosures}

Laurent Bonello received research grants from Astrazeneca, Boston and St Jude and lectures fees from Astrazeneca, Eli Lilly and Roche. Marc Laine received lectures fee from Astrazeneca.

\section{Funding}

Funding was provided by the Assistance Publique - Hopitaux de Marseille and Astrazeneca. This study was supported by a grant from AstraZeneca.

\section{References}

Management of Acute Coronary Syndromes in Patients Presenting without Persistent STSegment Elevation of the European Society of Cardiology. ESC Guidelines for the management of acute coronary syndromes in patients presenting without persistent STsegment elevation: Task Force for the Management of Acute Coronary Syndromes in Patients Presenting without Persistent ST-Segment Elevation of the European Society of Cardiology (ESC). Eur Heart J 2015;2016(37):267-315.

Kimmelstiel C, Zhang P, Kapur NK, Weintraub A, Krishnamurthy B, Castaneda V, Covic L, Kuliopulos A. Bivalirudin is a dual inhibitor of thrombin and collagen-dependent platelet activation in patients undergoing percutaneous coronary intervention. Circ Cardiovasc Interv 2011;4:171-179.

Braun D, Knipper A, Orban M, Sibbing D, Petzold T, Braun S, Schulz S, Hausleiter J, Kastrati A, Mehilli J, Massberg S. Platelet function and coagulation in patients with STEMI and peri-interventional clopidogrel plus heparin vs. prasugrel plus bivalirudin therapy (BRAVE 4 substudy). Thromb Res 2016;137:72-78. 
Navarese EP, Schulze V, Andreotti F, Kowalewski M, Kołodziejczak M, Kandzari DE, Rassaf T, Gorny B, Brockmeyer M, Meyer C, Berti S, Kubica J, Kelm M, Valgimigli M. Comprehensive meta-analysis of safety and efficacy of bivalirudin versus heparin with or without routine glycoprotein IIb/IIIa inhibitors in patients with acute coronary syndrome. JACC Cardiovasc Interv 2015;8:201-213.

Stone GW, Witzenbichler B, Guagliumi G, Peruga JZ, Brodie BR, Dudek D, Kornowski R, Hartmann F, Gersh BJ, Pocock SJ, Dangas G, Wong SC, Kirtane AJ, Parise H, Mehran R. HORIZONS-AMI Trial Investigators, bivalirudin during primary PCI in acute myocardial infarction. N Engl J Med 2008;358:2218-2230.

Valgimigli M, Frigoli E, Leonardi S, Rothenbühler M, Gagnor A, Calabrò P, Garducci S, Rubartelli P, Briguori C, Andò G, Repetto A, Limbruno U, Garbo R, Sganzerla P, Russo F, Lupi A, Cortese B, Ausiello A, Ierna S, Esposito G, Presbitero P, Santarelli A, Sardella G, Varbella F, Tresoldi S, De Cesare N, Rigattieri S, Zingarelli A, Tosi P, Van 'T Hof A, Boccuzzi G, Omerovic E, Sabaté M, Heg D, Jüni P, Vranckx P. MATRIX Investigators, bivalirudin or unfractionated heparin in acute coronary syndromes. N Engl J Med 2015;373:997-1009.

Steg PG, Van't Hof A, Hamm CW, Clemmensen P, Lapostolle F, Coste P, Berg JT, Grunsven PV, Eggink GJ, Nibbe L, Zeymer U, Campo Dell' Orto M, Nef H, Steinmetz J, Soulat L, Huber K, Deliargyris EN, Bernstein D, Schuette D, Prats J, Clayton T, Pocock S, Hamon M, Goldstein P. EUROMAX Investigators, bivalirudin started during emergency transport for primary PCI. N Engl J Med 2013;369:207-2217.

Han Y, Guo J, Zheng Y, Zang H, Su X, Wang Y, Chen S, Jiang T, Yang P, Chen J, Jiang D, Jing Q, Liang Z, Liu H, Zhao X, Li J, Li Y, Xu B, Stone GW. BRIGHT Investigators, bivalirudin vs heparin with or without tirofiban during primary percutaneous coronary intervention in acute myocardial infarction: The BRIGHT randomized clinical trial. Jama 2015;313:1336-1346.

Silvain J, Collet J-P, Nagaswami C, Beygui F, Edmondson KE, Bellemain-Appaix A, Cayla G, Pena A, Brugier D, Barthelemy O, Montalescot G, Weisel JW. Composition of coronary thrombus in acute myocardial infarction. J Am Coll Cardiol 2011;57:1359-1367.

Brummel-Ziedins K, Undas A, Orfeo T, Gissel M, Butenas S, Zmudka K, Mann KG. Thrombin generation in acute coronary syndrome and stable coronary artery disease: Dependence on plasma factor composition. J Thromb Haemost 2008;6:104-110.

Parodi G, Valenti R, Bellandi B, Migliorini A, Marcucci R, Comito V, Carrabba N, Santini A, Gensini GF, Abbate R, Antoniucci D. Comparison of prasugrel and ticagrelor loading doses in ST-segment elevation myocardial infarction patients: RAPID (Rapid Activity of Platelet Inhibitor Drugs) primary PCI study. J Am Coll Cardiol 2013;61:1601-1606.

Bonello L, Laine M, Camoin-Jau L, Noirot F, Guieu R, Dignat-George F, Paganelli F, Frere C. Onset of optimal P2Y12-ADP receptor blockade after ticagrelor and prasugrel intake in Non-ST elevation acute coronary syndrome. Thromb Haemost 2015;114:702-707.

Tantry US, Bonello L, Aradi D, Price MJ, Jeong Y-H, Angiolillo DJ, Stone GW, Curzen N, Geisler T, Ten Berg J, Kirtane A, Siller-Matula J, Mahla E, Becker RC, Bhatt DL, Waksman 
R, Rao SV, Alexopoulos D, Marcucci R, Reny J-L, Trenk D, Sibbing D, Gurbel PA. Working Group on On-Treatment Platelet Reactivity, Consensus and update on the definition of ontreatment platelet reactivity to adenosine diphosphate associated with ischemia and bleeding. J Am Coll Cardiol 2013;62:2261-2273.

Tamez H, Pinto DS, Kirtane AJ, Litherland C, Yeh RW, Dangas GD, Mehran R, Deliargyris EN, Ortiz G, Gibson CM, Stone GW. Effect of short procedural duration with bivalirudin on increased risk of acute stent thrombosis in patients with STEMI: A secondary analysis of the HORIZONS-AMI randomized clinical trial. JAMA Cardiol 2017. doi:10.1001/jamacardio.2016.5669.

De Caterina R, Husted S, Wallentin L, Andreotti F, Arnesen H, Bachmann F, Baigent C, Huber K, Jespersen J, Kristensen SD, Lip GYH, Morais J, Rasmussen LH, Siegbahn A, Verheugt FWA, Weitz JI. European society of cardiology working group on thrombosis task force on anticoagulants in heart disease, general mechanisms of coagulation and targets of anticoagulants (Section I). Position paper of the ESC working group on thrombosis-task force on anticoagulants in heart disease. Thromb Haemost 2013;109:569-579.

Schneider DJ, Keating F, Sobel BE. Greater inhibitory effects of bivalirudin compared with unfractionated heparin plus eptifibatide on thrombin-induced platelet activation. Coron Artery Dis 2006;17:71-476.

Garcia DA, Baglin TP, Weitz JI, Samama MM. American college of chest physicians, parenteral anticoagulants: antithrombotic therapy and prevention of thrombosis, 9th ed: American College of Chest Physicians evidence-based clinical practice guidelines. Chest 2012;141:24S-43S.

Laine M, Frere C, Cuisset T, Paganelli F, Morange P-E, Dignat-George F, Berbis J, CamoinJau L, Bonello L. Potential mechanism of acute stent thrombosis with bivalirudin following percutaneous coronary intervention in acute coronary syndromes. Int J Cardiol 2016;220:496500.

Ibanez B, James S, Agewall S, Antunes MJ, Bucciarelli-Ducci C, Bueno H, Caforio ALP, Crea F, Goudevenos JA, Halvorsen S, Hindricks G, Kastrati A, Lenzen MJ, Prescott E, Roffi M, Valgimigli M, Varenhorst C, Vranckx P, WidimskÝ P; ESC Scientific Document Group. The Task Force for the management of acute myocardial infarction in patients presenting with ST-segment elevation of the European Society of Cardiology (ESC) 2017 ESC guidelines for the management of acute myocardial infarction in patients presenting with ST-segment elevation. Eur Heart J 2017;00:1-66. doi:10.1093/eurheartj/ehx393.

Lincoff M, Bittl JA, Harrington RA, Feit F, Kleiman NS, Jackman JD, Sarembock IJ, Cohen DJ, Spriggs D, Ebrahimi R, Keren G, Carr J, Cohen EA, Betriu A, Desmet W, Kereiakes DJ, Rutsch W, Wilcox RG, De Feyter PJ, Vahanian A, Topol EJ. REPLACE-2 Investigators, bivalirudin and provisional glycoprotein IIb/IIIa blockade compared with heparin and planned glycoprotein IIb/IIIa blockade during percutaneous coronary intervention: REPLACE-2 randomized trial. JAMA 2003;289:853-863.

Lincoff AM, Bittl JA, Kleiman NS, Sarembock IJ, Jackman JD, Mehta S, Tannenbaum MA, Niederman AL, Bachinsky WB. Tift-Mann J 3rd, Parker HG, Kereiakes DJ, Harrington RA, Feit F, Maierson ES, Chew DP, Topol EJ; REPLACE-1 Investigators. Comparison of 
bivalirudin versus heparin during percutaneous coronary intervention (the Randomized Evaluation of PCI Linking Angiomax to Reduced Clinical Events [REPLACE]-1 trial). Am J Cardiol 2004;93:1092-1096.

Maegdefessel L, Buerke M, Schubert S, Reindl I, Michel T, Hauroeder B, Carter JM, Peetz D, Werdan K, Schlitt A. Comparison of bivalirudin, enoxaparin, and unfractionated heparin in preventing cardiac catheter thrombosis. Results of an in-vitro study. Thromb Haemost 2008;100:693-698.

Smythe MA, Koerber JM, Nowak SN, Mattson JC, Begle RL, Westley SJ, Balasubramaniam M. Correlation between activated clotting time and activated partial thromboplastin times. Ann Pharmacother 2002;36:7-11.

Atallah S, Liebl M, Fitousis K, Bostan F, Masud F. Evaluation of the activated clotting time and activated partial thromboplastin time for the monitoring of heparin in adult extracorporeal membrane oxygenation patients. Perfusion 2014;29:456-461.

Mousa SA, Zhang F, Aljada A, Chaturvedi S, Takieddin M, Zhang H, Chi L, Castelli MC, Friedman K, Goldberg MM, Linhardt RJ. Pharmacokinetics and pharmacodynamics of oral heparin solid dosage form in healthy human subjects. J Clin Pharmacol 2007;47:1508-1520.

Love JE, Ferrell C, Chandler WL. Monitoring direct thrombin inhibitors with a plasma diluted thrombin time. Thromb Haemost 2007;98:234-242.

\section{Additional information}

\section{Funding}

Funding was provided by the Assistance Publique - Hopitaux de Marseille and Astrazeneca. This study was supported by a grant from AstraZeneca. 